\title{
Rozlane krwawienie śródpęcherzykowe w przebiegu HIT typu II u pacjenta po przeszczepie serca z zatorowością płucną
}

\section{Diffuse alveolar hemorrhage in patient after heart transplantation and pulmonary embolism with heparin induced thrombocytopenia type II}

\author{
Marta Żarczyńska-Buchowiecka, Marcin Gruchała \\ I Katedra Kardiologii Gdańskiego Uniwersytetu Medycznego
}

\section{Streszczenie}

Typ II małopłytkowości indukowanej heparyną oraz rozsiane wykrzepianie wewnątrznaczyniowe charakteryzują się obecnością powikłań związanych z zaburzeniami hemostazy. W opisanym przypadku następstwem leczenia przeciwkrzepliwego zakrzepicy żył głębokich i zatorowości płucnej było krwawienie śródpęcherzykowe przebiegające pod maską masywnej pneumonii o prawdopodobnym atypowym czynniku etiologicznym.

Słowa kluczowe: rozlane krwawienie śródpęcherzykowe, małopłytkowość indukowana heparyną, rozsiane wykrzepianie wewnątrznaczyniowe, przeszczepienie serca, zatorowość płucna

Folia Cardiologica 2017; 12, 2: 196-199

\section{Wstęp}

Typ II małopłytkowości indukowanej heparyną (HIT, heparin-induced trombocytopenia) jest potencjalnie zagrażającym życiu powikłaniem leczenia heparyną niefrakcjonowaną, a w rzadszych przypadkach również drobnocząsteczkową (LMWH, low molecular weight heparin) [1]. Podstawami diagnostyki tego powikłania są obraz kliniczny oraz wyniki badań laboratoryjnych. Poniżej opisano historię pacjenta z rozlanym krwawieniem śródpęcherzykowym (DAH, diffuse alveolar hemorrhage) w następstwie HIT oraz maskę kliniczną i radiologiczną tego groźnego powikłania pod postacią zapalenia płuc.

\section{Opis przypadku}

Chory w wieku 73 lat został przyjęty z Pomorskiego Centrum Chorób Zakaźnych i Gruźlicy, gdzie był hospitalizowany z powodu zakażenia układu moczowego o etiologii
E. faecalis oraz ciężkiej biegunki o etiologii C. difficile. Biegunka wystąpiła po antybiotykoterapii włączonej ambulatoryjnie z powodu infekcji dolnych dróg oddechowych. W wywiadzie stwierdzono stan po przeszczepieniu serca z powodu wieńcowopochodnej schyłkowej niewydolności serca (2000 r.), waskulopatię serca przeszczepionego, stan po angioplastyce gałęzi okalającej z implantacją stentu uwalniającego lek (2012 r.), przewlekłą choroba nerek w III stadium w przebiegu terapii inhibitorem kalcyneuryny. Do kliniki kardiologii skierował pacjenta konsultujący na dyżurze kardiolog z powodu pogorszenia stanu ogólnego, duszności oraz asymetrycznych obrzęków podudzi z dodatnim objawem Homansa po lewej stronie. Wysunięto podejrzenie zatorowości płucnej w przebiegu zakrzepicy żył głębokich.

Przy przyjęciu chory był w dość dobrym stanie ogólnym, bez dolegliwości spoczynkowych, miarowa akcja serca wynosiła 80/min, ciśnienie tętnicze 140/80 mm Hg, RR 18/ /min, saturacja tlenem hemoglobiny krwi tętniczej $\left(\mathrm{O}_{2}\right) 95 \%$ bez tlenoterapii biernej; osłuchowo nad polami płucnymi

Adres do korespondencji: dr n. med. Marta Żarczyńska-Buchowiecka, I Katedra Kardiologii, Gdański Uniwersytet Medyczny, ul. Marii Curie-Skłodowskiej 3a, 80-210, Gdańsk, e-mail: mzarczynska@gumed.edu.pl 
stwierdzono szmer pęcherzykowy z pojedynczymi trzeszczeniami u podstawy obu płuc. W badaniu radiologicznym (RTG) klatki piersiowej wykonanym w Pomorskim Centrum Chorób Zakaźnych i Gruźlicy uwidoczniono ślad płynu w lewym kącie przeponowo-żebrowym, poza tym miąższ płucny i sylwetka serca nie wykazywały odchyleń. W zapisie elektrokardiograficznym (EKG) stwierdzono miarowy rytm zatokowy wynoszący 90/min, blok prawej odnogi pęczka Hisa (RBBB, right bundle branch block), brak zmian odcinka ST-T. W badaniu echokardiograficznym uwidoczniono dobrą kurczliwość mięśnia lewej komory z frakcją wyrzutową lewej komory (LVEF, left ventricular ejection fraction) równą 65\%, szeroką prawą komore (wewnętrzny wymiar prawej komory w rozkurczu [RVIDd, right ventricular internal dimension in diastole] $61 \mathrm{~mm}$ ) o obniżonej kurczliwości (amplituda ruchu pierścienia trójdzielnego [TAPSE, tricuspid annular plane systolic excursion] $11 \mathrm{~mm}$ ), z towarzyszącym spłaszczeniem przegrody międzykomorowej, istotnie skrócony czas akceleracji przepływu przez tętnice płucną ([AcT PA, acceleration time pulmonary artery] 55 ms), masywną niedomykalność zastawki trójdzielnej, maksymalną prędkość fali zwrotnej przez zastawkę trójdzielną (TR Vmax, maximal tricuspid regurgitation velocity) $420 \mathrm{~cm} / \mathrm{s}$, szeroką żyłę główną dolną (IVC, inferior vena cava) o zmniejszonej zapadalności oddechowej, ciśnienie skurczowe prawej komory (RVSP, right ventricular systolic pressure) ponad $80 \mathrm{~mm} \mathrm{Hg}$, bez płynu w worku osierdziowym. W badaniu ultrasonograficznym (USG) układu żylnego kończyn dolnych stwierdzono rozległe, w większości zamykające światło, świeże zmiany zakrzepowe w lewej kończynie dolnej. Ze względu na wywiad zaostrzenia przewlekłej choroby nerek wymagającej przejściowych hemodializ, najprawdopodobniej związany z podaniem środka kontrastowego w przeszłości, odstąpiono od badania angiotomografii komputerowej tętnic płucnych. Wykonano scyntygrafię perfuzyjną płuc, stwierdzając obraz przemawiający za obecnością zatorowości płucnej.

$W$ badaniach laboratoryjnych stężenie peptydu natriuretycznego typu B (BNP, B-type natriuretic peptide) wynosiło 983 pg/ml, a markery martwicy mięśnia sercowego były niepodwyższone. W morfologii krwi obwodowej stwierdzono niedokrwistość normocytarną normobarwliwą, z wartością hemoglobiny ( $\mathrm{Hb}$, hemoglobin) 9,3 g/dl, z niewielkimi odchyleniami w stężeniu żelaza oraz jego związków związanych i niskim stężeniem kwasu foliowego, liczbą płytek (PLT, platelets) $151 \mathrm{G} / \mathrm{l}$, liczbą krwinek białych (WBC, white blood cells) 4,62 G/I, liczbą granulocytów 2,42 G/I, stężeniem białka C-reaktywnego (CRP, C-reactive protein) $71 \mathrm{mg} / \mathrm{l}$, stężeniem D-dimerów $2560 \mu \mathrm{g} / \mathrm{l}$, mianem DNA wirusa Epstein-Barr (EBV, Epstein-Barr virus) 935 kopii/ml. Nie stwierdzono obecności DNA wirusa cytomegalii (CMV, cytomegalovirus), nie wykryto wczesnego antygenu CMV, a wyniki badań Candida mannan i Aspergillus galaktomannan powinny być ujemne. Stwierdzono również terapeutyczne wartości leków immunosupresyjnych (ewerolimus i mykofenolan mofetilu).
Rozpoznano zatorowość płucną pośredniego ryzyka. Włączono leczenie za pomocą LMWH oraz zastosowano pończochy o stopniowanym ucisku. Wdrożono również suplementację kwasu foliowego. Kontynuowano antybiotykoterapię rozpoczętą w Pomorskim Centrum Chorób Zakaźnych i Gruźlicy. Ze względu na obecność kopii wirusa EBV ograniczono również leczenie immunosupresyjne.

W 8. dobie hospitalizacji doszło do pogorszenia stanu ogólnego pacjenta, nasilenia duszności, kaszlu, pojawienia się krwioplucia o niewielkim nasileniu, akcja serca wynosiła 110/min, ciśnienie tętnicze 120/80 mm Hg, RR 24/min, osłuchowo nad polami płucnymi stwierdzono trzeszczenia u podstawy obu płuc, saturacja $\mathrm{O}_{2}$ w pomiarze przezskórnym bez tlenoterapii wynosiła 78-80\%, z cechami częściowej niewydolności oddechowej w gazometrii krwi tętniczej $\left(\mathrm{pO}_{2} 51 \mathrm{~mm} \mathrm{Hg}\right)$. Oznaczony poziom PLT, zarówno na EDTA (ethylenediaminepentaacetic acid) jak i cytrynian, wykazał małopłytkowość na poziomie $38 \mathrm{G} / \mathrm{I}$ oraz pogłębiająca się niedokrwistość - Hb $7 \mathrm{~g} / \mathrm{dl}$, obserwowano rosnące stężenie CRP 107 mg/l z wyższymi niż wyjściowo wartościami leukocytów oraz granulocytów, ale utrzymującymi się w górnej granicy normy oraz tylko nieznacznie podwyższoną wartością prokalcytoniny (PCT, procalcitonin) $0,83 \mathrm{ng} / \mathrm{ml}$, stężenie BNP 1050 pg/ml i stężenie D-dimerów $4363 \mu \mathrm{g} / \mathrm{l}$. Oddechowy panel wirusologiczny był ujemny. W trybie pilnym wykonano tomografię komputerową wysokiej rozdzielczości (HRCT, high-resolution computed tomography), stwierdzając w obu płucach rozsiane zmiany śródmiąższowe o cechach matowej szyby. Według konsultującego radiologa obraz płuc mógł przemawiać za obecnością zmian zapalnych wywołanych atypowym czynnikiem, najprawdopodobniej z grupy Pneumocystis. Włączono szerokospektralną antybiotykoterapie, w tym makrolid oraz sulfametoksazol z trimetoprimem. Potwierdzono rozpoznanie HIT, stwierdzając dodatnie przeciwciała przeciwko kompleksowi PF-4 z heparyną. Odstawiono LMWH i włączono fondaparinux. W kolejnych badaniach obserwowano wydłużenie czasu częściowej tromboplastyny po aktywacji (APTT, activated partial thromboplastin time) i czasu protrombinowego (PT, prothrombin time), rosnące stężenie D-dimerów, a także podkrwawianie z miejsca wkłucia głębokiego, błon śluzowych oraz okresowe odkrztuszanie plwociny podbarwionej krwią, co skłoniło do rozpoznania rozsianego krzepnięcia wewnątrznaczyniowego (DIC, disseminated intravascular coagulation), mimo podwyższonej wartości fibrynogenu (5,5 G/l). Przetoczono łącznie 3 j. koncentratu krwinek czerwonych (kkcz) oraz 6 j. świeżo mrożonego osocza (FFP, fresh frozen plasma) - bez powikłań.

Zważywszy na całokształt obrazu klinicznego, wysunięto podejrzenie DAH. Wykonano bronchofiberoskopię oraz badanie popłuczyn oskrzelowo-pęcherzykowych (BAL, bronchoalveolar lavage). Na podstawie badań serologicznych i mikrobiologicznych materiału uzyskanego z badania wykluczono tło infekcyjne zmian w płucach. W nadesłanym 
materiale dominowały krwinki czerwone, część z nich z cechami hemolizy. Spośród elementów jądrzastych przeważały makrofagi stanowiące około 90\% elementów, około $65 \%$ z nich wykazywało cechy pigmentacji (hemosyderofagi). W badanym materiale nie stwierdzono obecności komórek nowotworowych. Przeprowadzona diagnostyka immunologiczna w kierunku zespołu antyfosfolipidowego oraz zapalenia naczyń była ujemna.

Odstawiono sulfametoksazol z trimetoprimem, podawano etamsylat, stosowano tlenoterapię bierną oraz fondaparinux pod ścisła kontrolą parametrów nerkowych. Po konsultacji pneumonologicznej zadecydowano o niewłączaniu steroidoterapii.

W trakcie hospitalizacji wystąpiła również biegunka. Wyniki badania w kierunku toksyny A i B C. difficile ponownie były dodatnie. Włączono doustne leczenie wankomycyną. W badaniu kontrolnym nie stwierdzono obecności toksyny. Obserwowano stopniową poprawę stanu ogólnego oraz normalizację parametrów morfologicznych. W kontrolnym badaniu USG układu żył lewej kończyny dolnej stwierdzono bardzo słaby postęp rekanalizacji w porównaniu z poprzednim badaniem. Wdrożono leczenie warfaryną. W badaniach laboratoryjnych przy wypisaniu ze szpitala wartości oznaczonych parametrów były następujące: stężenie Hb 11,1 G/I, liczba PLT 252 G/l, układ białokrwinkowy w normie, stężenie CRP 34 mg/l, stężenie BNP 413 pg/ml, wartość międzynarodowego wskaźnika znormalizowanego (INR, international normalized ratio) 2,46 po wysyceniu doustnym antykoagulantem. Pacjenta wypisano do domu w dobrym stanie ogólnym z zaleceniem dalszego leczenia w ramach opieki ambulatoryjnej.

\section{Dyskusja}

W odróżnieniu od HIT typu I, w wywołanym mechanizmami immunologicznymi typie II dochodzi do znacznego zmniejszenia liczby PLT, zwykle do poziomu 30-50 G/I, typowo po 5-10 dniach stosowania heparyny [2]. W opisywanym przypadku, po wykluczeniu małopłytkowości rzekomej wynikającej z aglutynacji płytek in vitro z krwi pobranej na EDTA (ethylenediaminepentaacetic acid) oraz w związku z okolicznościami klinicznymi, wysunięto podejrzenie immunologicznej małopłytkowości poheparynowej. W ustaIeniu rozpoznania posiłkowano się regułą predykcyjną 4T (thrombocytopenia - małopłytkowość, timing - czas do wystąpienia małopłytkowości lub zakrzepicy, thrombosis - zakrzepica, other causes of thrombocytopenia not evident - inne przyczyny małopłytkowości nieoczywiste). Służy ona do oceny prawdopodobieństwa wystąpienia HIT przed testem, a jej szczególną zaletą jest wysoka negatywna wartość predykcyjna u pacjentów z grupy niskiego ryzyka [3]. Do potwierdzenia rozpoznania HIT wykorzystuje się obecność przeciwciał przeciw płytkowemu czynnikowi 4/heparynie (PF4/H, platelet factor 4/heparin), jednak wynik tego oznaczenia nie powinien opóźniać wdrożenia postępowania u pacjentów z grup umiarkowanego i wysokiego ryzyka wystąpienia HIT [2]. Obiecujące są nowe, szybkie testy laboratoryjne, które pozwalają na uzyskanie wyniku w ciągu 15 minut [4].

W małopłytkowości objawy skazy krwotocznej pod postacią drobnych wybroczyn na skórze, krwawień z dziąseł, dróg moczowych czy rodnych pojawiają się zwykle przy

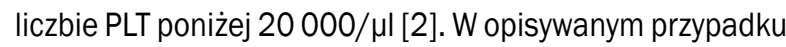
jednak krwioplucie pojawiło się przy wyższej liczbie płytek, prawdopodobnie z powodu współistnienia DIC oraz leczenia przeciwkrzepliwego. Podwyższone stężenie fibrynogenu nie jest typowe dla DIC, w którym obserwuje się raczej jego obniżenie [2]. Ponieważ jest to jednak białko ostrej fazy, to w stanach ostrych dochodzi do jego wzrostu. Poza przypadkami zagrażających życiu krwawień nie zaleca się profilaktycznego przetaczania koncentratu krwinek płytkowych ze względu na zwiększone ryzyko powikłań zakrzepowych [5]. W opisywanym przypadku, z powodu towarzyszącego DIC oraz cech krwawienia śródpęcherzykowego z narastającą dusznością, stosowano FFP oraz kkcz. Rozpoznania tego dokonano jednak z opóźnieniem, na które wpłynęło przekonanie o infekcyjnej przyczynie pogorszenia stanu klinicznego chorego pozostającego w trakcie immunosupresji. Chociaż powikłania infekcyjne po przeszczepieniu narządów są najczęstsze u chorych w ciągu pierwszych 4-6 miesięcy, to sugestywny obraz radiologiczny w opisywanym przypadku oraz wysokie stężenie CRP, choć bez towarzyszącego wzrostu liczby WBC i przy tylko niewielkim wzroście liczby PCT, wskazywały raczej na infekcyjną przyczynę niewydolności oddechowej. Wiadomo, że przebieg zakażeń u biorców przeszczepów charakteryzuje się zmodyfikowaną dynamiką wynikająca z leczenia immunosupresyjnego. Odpowiedź zapalna jest zredukowana, nierzadko dochodzi więc do szybkiego zajęcia narządów przy skąpoobjawowym przebiegu zakażenia. Ze względu na pogarszający się stan kliniczny uzasadnione wydawało się włączenie intensywnego empirycznego leczenia przeciwdrobnoustrojowego. Jednakże nefrotoksyczność leków, zwłaszcza stosowanego w dawkach terapeutycznych sulfametoksazolu z trimetoprimem u pacjenta z wywiadem przewlekłej choroby nerek, mogła wpłynąć na pogłębienie dysfunkcji narządu z nasileniem duszności wtórnym do retencji płynów. Ponadto w przypadku powikłań infekcyjnych o ciężkim przebiegu zaleca się ograniczenie podaży leków immunosupresyjnych, co w skrajnych przypadkach może prowadzić do groźnego powikłania, jakim jest odrzut przeszczepionego narządu. Ostatecznie w opisywanym przypadku, z powodu wysokiego prawdopodobieństwa DAH (duszność, kaszel, krwioplucie, hipoksemia, niedokrwistość i obraz matowej szyby w HRCT wynikający z wypełnienia pęcherzyków płucnych przez wynaczynioną krew), rozpoznanie to potwierdzono w badaniu mikroskopowym materiału pobranego w trakcie bronchofiberoskopii i BAL. 
Stwierdzenie obecności hemosyderofagów w BAL pozwoliło ostatecznie postawić trafną diagnoze - „rozlane krwawienia śródpęcherzykowe w przebiegu małopłytkowości indukowanej heparyną i zespołu rozsianego wykrzepiania wewnątrznaczyniowego".

\section{Podsumowanie}

W leczeniu HIT zaleca się biwalirudynę, lepirudynę i argotroban, które ze względu na mniejszą dostępność oraz wysoką cenę w praktyce klinicznej chętnie są zastępowane selektywnym inhibitorem czynnika Xa - fondaparinuxem, co uważa się za bezpieczne i skuteczne [2]. Być może, słaby efekt leczenia przeciwzakrzepowego w badaniu kontrolnym żył kończyny dolnej metodą Dopplera wynikał z powikłań leczenia przeciwkrzepliwego. Wiadomo bowiem, że nawet w 30-75\% przypadków HIT towarzyszą powikłania zakrzepowe, zarówno w układzie żylnym, jak i tętniczym [2].

\section{Konflikt interesów}

Autorzy oświadczają, że nie zachodzi żaden konflikt interesów w związku z publikowaną pracą.

\section{Abstract}

Type II heparin-induced thrombocytopenia and disseminated intravascular coagulation are characterized by presence of complications resulting from haemostatic disorders. In described case report diffused intra-alveolar bleeding occurred as a result of the low molecular weight heparin treatment of deep vein thrombosis and pulmonary embolism. The clinical presentation resembled massive pneumonia of atypical etiology rather than bleeding complication.

Key words: diffuse alveolar hemorrhage, disseminated intravascular coagulation, heparin-induced thrombocytopenia, heart transplantation, pulmonary embolism

Folia Cardiologica 2017; 12, 2: 196-199

\section{Piśmiennictwo}

1. Martel N, Lee J, Wells PS. Risk for heparin-induced thrombocytopenia with unfractionated and low-molecular-weight heparin thromboprophylaxis: a meta-analysis. Blood. 2005; 106(8): 2710-2715, doi: 10.1182/blood-2005-04-1546, indexed in Pubmed: 15985543.

2. www.interna.mp.pl (15.07.2016).

3. Lo GK, Juhl D, Warkentin TE, et al. Evaluation of pretest clinical score (4 T's) for the diagnosis of heparin-induced thrombocytopenia in two clinical settings. J Thromb Haemost. 2006; 4(4): 759765, doi: 10.1111/j.1538-7836.2006.01787.x, indexed in Pubmed: 16634744
4. Jourdy $Y$, Nougier C, Rugeri L, et al. Prospective evaluation of automatized PF4/heparin immunoassays HemosIL HIT-ab (PF4-H) for the diagnosis of heparin-induced thrombocytopenia. Int J Lab Hematol. 2015; 37(2): 244-252, doi: 10.1111/ijlh.12275, indexed in Pubmed: 25041633.

5. Warkentin TE. Heparin-induced thrombocytopenia: pathogenesis and management. Br J Haematol. 2003; 121(4): 535-555, indexed in Pubmed: 12752095. 